\title{
The impact of FDI on the performance and entrepreneurship of domestic firms
}

\section{Mico Apostolov}

\section{Journal of International \\ Entrepreneurship}

ISSN 1570-7385

Volume 15

Number 4

J Int Entrep (2018) 15:390-415

DOI 10.1007/s10843-017-0205-4

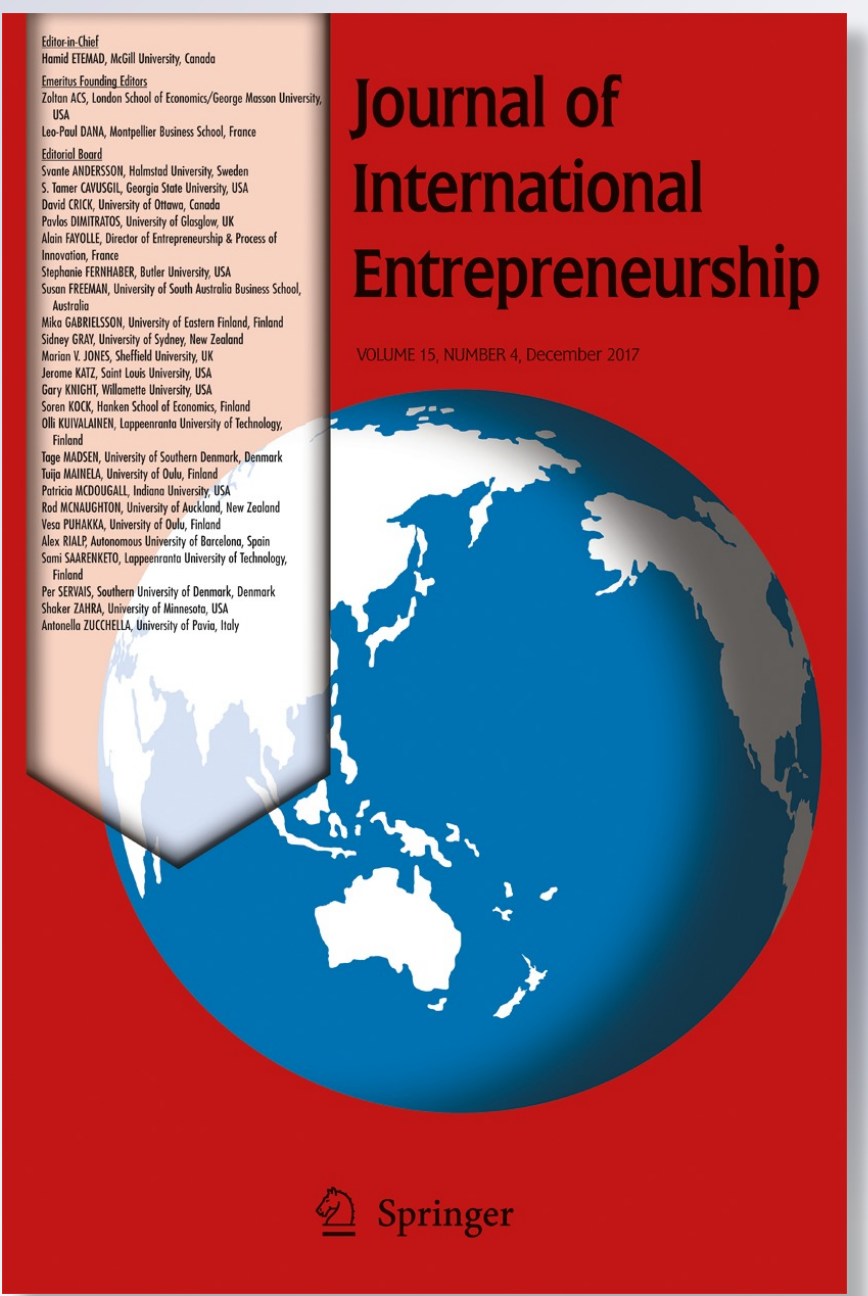

Springer 
Your article is protected by copyright and all rights are held exclusively by Springer Science+Business Media, LLC. This e-offprint is for personal use only and shall not be selfarchived in electronic repositories. If you wish to self-archive your article, please use the accepted manuscript version for posting on your own website. You may further deposit the accepted manuscript version in any repository, provided it is only made publicly available 12 months after official publication or later and provided acknowledgement is given to the original source of publication and a link is inserted to the published article on Springer's website. The link must be accompanied by the following text: "The final publication is available at link.springer.com". 


\title{
The impact of FDI on the performance and entrepreneurship of domestic firms
}

\author{
Mico Apostolov ${ }^{1,2}$ (D) \\ Published online: 12 June 2017 \\ (C) Springer Science+Business Media, LLC 2017
}

\begin{abstract}
This paper examines how foreign direct investments influence the performance and entrepreneurship of domestic firms, a crucial question for economies driven by incursion of exogenous factors and especially transition economies. The intent is to investigate the way foreign direct investments shape the capabilities of domestic firms; hence, for this purpose, we take Macedonia, a Southeast European economy, as a case study. We find that (i) foreign ownership has helped restructure and enhance the productivity of domestic firms, (ii) FDI has positive influence in reinforcing the creation of new firms, and (iii) in line with the established literature, a foreign investment is likely to influence the job seeker to get employed rather to start their own business. Overall, the results confirm the influence of foreign firms in assisting entrepreneurial activity. The impact of foreign investment is, in general, positive and tends to influence the restructuring process of domestic enterprises.

Résumé Cet article examine comment les investissements directs étrangers influencent la performance et l'entrepreneuriat des entreprises nationales, question cruciale pour les économies entraînées par l'incursion de facteurs exogènes et surtout des économies en transition. L'objectif est. d'enquêter comment les investissements étrangers directs façonnent les capacités des entreprises nationales; par conséquent, on prend la Macédoine, une économie de l'Europe du Sud-est, comme étude de cas. Partant, on trouve que: (i) la propriété étrangère a aidé à restructurer et à améliorer la productivité des entreprises nationales; (ii) l'IED a une influence positive sur le renforcement de la création de nouvelles entreprises, et (iii) conformément à la littérature établie, un investissement étranger est. susceptible d'influencer le demandeur d'emploi à s'engager
\end{abstract}

The author is an alumnus of Scuola Superiore Sant'Anna (Normale di Pisa), Pisa, Italia, an alumnus of University of California, Berkeley - Haas School of Business, CA, USA and anciens du Collège d'Europe, Bruges/Natolin

Mico Apostolov

mico.apostolov@ugd.edu.mk; mico.apostolov@unito.it; http://www.micoapostolov.com/; http:// scholar.ugd.edu.mk/micoapostolov

1 Present address: UGD, Krste Misirkov b.b, P.O. Box 201, 2000 Stip, Macedonia

2 Dipartimento di Management, Università degli Studi di Torino, Corso Unione Sovietica 218-bis, 10134 Torino, Italy 